\title{
The Effect of School-based Exercise Practices of 9-11 Year Old Girls Students on Obesity and Health-related Quality of Life
}

\author{
Nevzat Demirci ${ }^{1, *}$, Pervin Toptaş Demirci ${ }^{2}$, Erdal Demirci ${ }^{3}$ \\ ${ }^{1}$ School of Physical Education and Sports, Mersin University, Turkey \\ ${ }^{2}$ Department of Tourism Animation Programme, Mersin University, Turkey \\ ${ }^{3}$ Sarıkamış School of Physical Education and Sport Sciences, Kafkas University, Turkey \\ *Corresponding Author: nevzatdemirci44@hotmail.com
}

Copyright $\mathrm{C} 2017$ by authors, all rights reserved. Authors agree that this article remains permanently open access under the terms of the Creative Commons Attribution License 4.0 International License

\begin{abstract}
This study was planned to determine the effects of school-based exercise practices (SBEP) on obesity and health-related quality of life (HRQL) in 9-11 year old girls. Participants consist of girls students from 9-11 years old in two state schools in Kars. Intervention Group (n: 85) courses of games and physical activities (CGPA) and SBEP (Basketball, Handball, Volleyball, Badminton, Table Tennis) and Control Group (n: 85) were formed as only CGPA. The exercise program; intervention groups was made subject to a training load of $60-70 \%$ and repetitions making up 3 days a week for 60 minutes a day, whereas the control group is a compulsory lesson 45 minutes three days a week in the gym or playground. Health-Related Quality of Life Scale (Kid-KINDL) was used in order to define the girl student quality of life before and after SBEP while Exercise Self-Efficacy Scale (ESS) was used for determining their exercise levels. According to the findings; Intervention group was found to be significant at $\mathrm{p}<.001$ level according to the height, weight and body mass index control group of girl students. 4 months after intervention, the proportion of obesity in the intervention group was $25.2 \%$ and the rate of overweight was $14.2 \%$ while it was observed that the control group had a statistically insignificant decrease in BMI. Intervention group's scores of sub-dimensions of total quality of life, physical well-being, emotional well-being, self-esteem, family as well as exercise self-efficacy levels $(E S L)$ were observed significantly high $(p<0.001)$ compared to control group. A positive relationship $(\mathrm{p}<0.01 ; \mathrm{p}<0.05)$ at the level of $r=.361 ; r=.305 ; r=.219$ was found between ESL and the sub-dimensions of physical well-being, emotional well-being and self-esteem of HRQL of intervention group while a significant relationship $(p<0.05)$ at the level of $\mathrm{r}=.230$ was determined between ESL and the sub-dimension of friends of HRQL Scale of control group. Consequently, Female students have a positive effect on ESL and HRQL. Obesity rate decreases as ESL increases and HRQL levels also increase significantly. SBEP participation should be
\end{abstract}

increased at the point of increasing HRQL in children's daily lives and educational settings.

Keywords School-based Exercise, Exercise Self-efficacy, Quality of Life, Obesity

\section{Introduction}

Obesity and overweight in the present century is the most important issue in the world. The highest increase in the prevalence of obesity in most countries is a source of global concern [1]. Obesity and overweight are the fifth cause of death in the world and 2.6 million people die from this disease per year [2]. The health problems have increasingly and varyingly emerged among children and adolescents since the previous century [3]. There are a great number of health outcomes related to a physically inactive life-style, including an increased risk of various diseases such as diabetes, breast cancer, colon cancer, stroke, hypertension and coronary artery disease [4]. Performing physical activities regularly not only prevents chronic diseases but also improves health-related quality of life (Kid-KINDL). Quality of life expresses how people see the positive and negative aspects of their lives subjectively and it encompasses the psychological and physical factors that are influential on people's general perception on satisfaction with their lives $[5,6]$. Quality of life is a comprehensive concept involving the state of personal well-being beyond personal health. Health-related quality of life can be expressed as the individual response given in daily life to the physical, mental and social impacts of the disturbances that affect the individual satisfaction under certain life conditions. Therefore, measurement of quality of life has a more comprehensive concept and understanding compared to the criteria on the health state $[7,8]$. 
School environments offer many opportunities for SBEP intervention programs for students [9]. Children spend considerable time during the day to ensure their health-related quality of life and habits develop. Therefore, the SBEP is seen as the main options recommended for school-age children to increase daily PA [10]. Although the PA is often carried out by school-age children outside the school environment, the SBEP plays an important role in the protection of health [11]. However, although the positive relationship between SBPD and leisure time activities was confirmed even in the non-obese school age children, the positive relationship between SBPD was still not well researched [12]. Globally, efforts to prevent obesity in childhood have led to the implementation of a number of school interventions [13]. For example, increased PA (reduced sedentary behavior) combination appears to be more effective than a suitable diet alone or alone in reducing obesity in appropriate diets. Likewise, long-term $(>1$ year) interventions are more likely to reduce obesity than short-term ( $<1$ year) interventions. Moreover, sex-specific interventions seem to be more effective in reducing obesity than general interventions [14]. Although the prevalence of obesity in childhood changes significantly from country to country and from year to year, obesity rates are still high and alarming. Although there are no broad-based studies investigating the prevalence of obesity in school age children in our country, the prevalence of obesity in regional studies has been reported between $9 \%$ and $27 \%$ [15].

Self-efficacy is based on the theory that it has a strong influence on the individual behaviours, motivation and achievement of the objectives. In his theory, Bandura [16, 17] defines "self-efficacy" as a person's capabilities and confidence to organize and perform an action required for managing potential situations [18]. A relationship has been seen between children's physical activity level and physical self-efficacy scores $[19,20]$. Therefore, understanding the factors influential on the physical activity and encouraging an active life style plays a significant role to prevent such diseases as diabetes and hypertension. Lack of physical activity in childhood supports the hypothesis that it contributes to development of over-weight and obesity [21, 22].

Some studies have been carried out in order to examine the overweight and obese children's and adolescents' health-related quality of life in recent years [23, 24, 25]. Researchers have found that BMI has a negative relationship with the health-related quality of life and it is observed more frequently among women compared to men $[24,26]$. In another study, it has been observed that physical activity is directly related with the quality of life among the adults irrespective of their weights [27]. Researchers have recently suggested that both physical activity and fitness may have an important effect on improvement of the old adults' health-related quality of life [28]. It has been put forward in another study [29] that physical activity, exercise self-efficacy and physical self-esteem may be influential on the quality of life. This study was planned to determine the effects of school-based exercise practices (SBEP) on obesity and health-related quality of life (HRQL) in 9-11 year old girls. To compare obesity, ESL and HRQL levels of intervention and control groups are girls' student before and after the intervention. The purpose another of this study is to define whether there is a relationship between the quality of life and exercise self-efficacy level of the girl students that take part in SBEP and those not.

\section{Material and Methods}

\subsection{Participants}

The participants of this study were selected among the volunteer girl students attending the third and fourth grade at a two state school in Kars in 2014-2015 academic year. The participants were selected randomly and intervention group (n: 85) and from control group girl students (n:85) were formed. The students who have taken part in the CGPA as well as SBEP (basketball, handball, volleyball, badminton, table tennis) were included in intervention group while those have participated only in the CGPA constituted control group. This study aims to compare the students' HRQL perceptions and ESL. The participants' body height was measured on bare foot using a tape measure fixed to wall while their body weight was measured through an electronic weighing machine when they wore shorts. Body Mass Index (BMI) was accounted for all the children with the help of the balance called "Body Weight $(\mathrm{kg}) /$ Length of Body $(\mathrm{m})^{2}$ ". The results of BMI were classified according to WHO 2007 5-19 age reference values and the person's values that WHO suggests. Where overweight and obesity represented the 85-97 and $>97$ percentiles respectively of age-differentiated BKI [30]. The required permits were obtained from the Provincial Directorate of National Education of Kars, the relevant school and parents for this study that was carried out in accordance with the instruction given in Helsinki Declaration. The participants were involved in the research voluntarily. Before starting the research, the rules required to be followed were explained in detail to the students and then a consent form was signed by them.

\subsection{Procedure}

In the Intervention group school there were gymnasiums and playgrounds for suitable settings and course activities for SBEP (Basketball, Handball, Volleyball, Badminton, Table Tennis). On the contrary, only the school garden could be used for CGPA in the control group school. In both the intervention group and the control group schools, baseline measurements were made before the students began SBEP and CGPA. The application programs were organized by the physical education and sports teachers in the schools in cooperation with the students. Then, the control group 
schools continued with the standard CGPA program, while the intervention group started with the SBEP. The standard CGPA program (both intervention and control group) was implemented in schools. The CGPA is a compulsory 45 minutes three days a week in the gym or playground. CGPA program; on the focuses movement games, games based on locomotive motions, general physical development through throwing, catching or jumping, running, spinning, passing and simple gymnastic exercises. In addition to the standard program for a period of 4 months, the intervention groups was made subject to a training load of $60-70 \%$ and repetitions making up 3 days a week for 60 minutes a day. In addition to the standard program, 3 days a week for 60 minutes a day. SBEP (only intervention group schools). 10-minute warm-up exercise session was held before the SBEP. For the SBEP program (Basketball, Handball, Volleyball, Badminton, Table Tennis); Branch-specific basic techniques such as walking, running, jump, dribbling, shooting were applied. In addition, direction change movements, backhand and forehand strokes and aerobic runs were applied. SBEP is freed to change the pattern and intensity of exercise as it is based on participants' preferences and abilities. Short breaks of 5 minutes were given during SBEP. SBEP was conducted by the teachers of physical education and under the supervision of the researchers during 4 months.

\subsection{Data Collection Tools}

Consisting of 18 items, the Exercise Self-Efficacy Scale (ESS) that was developed by Bandura [16] and expressed in 0-100 scores was used in order to define the exercise levels while Kid-KINDL Health-Related Quality of Life (HRQL) was used to assess the health-related quality of life.

\subsection{Exercise Self-Efficacy Scale (ESS)}

Exercise Self-Efficacy Scale measures a person's perceived self-efficacy confidence. The scale is a measure of self-statement and consists of 18 self-efficacy items that require the subjects to show their confidence in performing the physical activities and exercises. Exercise Self-Efficacy Scale was developed by Bandura and its validity and reliability studies were carried out by Bozkurt with the patients with breast cancer in Turkey. The test-retest reliability coefficient was found $0.968[16,31]$. ES Scale consists of 18 items that can be scored between $0 \%$ and $100 \%$. The participants are scored by 100 points with 10 -unit intervals ranging from 0 to 50 ("Moderately certain can do") and 100 ("Highly certain can do") according to the level or power of confidence in their self-efficacy. The internal consistency reliability was found 0.94 [31].

\subsection{Health-Related Quality of Life Scale (Kid-KINDL)}

Developed specially for children and adolescents by Ravens- Sieberer and Bullinger in 1998, KINDL (KINDer Lebensqualitätsfragebogen: Children Quality of Life Questionnaire) is an instrument for measuring general-purpose quality of life. KINDL was developed in the German language and translated into 14 languages. Eser et al. performed the validity and reliability studies of the scale for the Turkish language for the children aged between 8 and 12 [8]. The questionnaire has 24 items and sub-dimensions including 5-likert options. The scale includes six sub-dimensions including physical well-being, emotional well-being, self-esteem, family, friends and school (school or nursery school/kindergarten for everyday functioning). Each sub-dimension has 4 items. While the scores for the sub-dimensions are independently calculated, these six sub-dimensions are combined to produce a score of total quality of life. The scores obtained from the scale range between 0 and 100. The scale doesn't have any breakpoint. Getting high score means well-being in quality of life. The items of Kid-KINDL are ranged from 1 (never) to 5 (all the time) and scaled with likert-type measure.

\subsection{Analysis}

All statistical analyses were performed by SPSS version 20.0. Results of descriptive statistics in this study are presented as mean, standard deviation, and percentage rates. Mann Whitney U test was used for the paired comparisons because the data doesn't have a normal distribution while Spearman correlation test was used in order to define the relationships between the variables. The fact that $\mathrm{P}$ was less than 0.05 was considered significant.

\section{Results}

The intervention groups mean values of participants were $9.94 \pm 0.80$ years for age, $143.93 \pm 6.13 \mathrm{~cm}$ for body height, $37.34 \pm 4.82 \mathrm{~kg}$ for body weight and $18.10 \pm 2.55$ for BMI, and control group $9.96 \pm 0.77$ years for age, $141.24 \pm 5.93 \mathrm{~cm}$ for body height, $39.18 \pm 5.98 \mathrm{~kg}$ for body weight and $19.87 \pm 2.42$ for BMI respectively. (Table 1). There was no significant difference between students in the physical properties (such as age, height, weight and BMI) at the baseline. When the groups' physical characteristics were compared, a significant difference wasn't observed in terms of age between them. Nonetheless, after 4 months from intervention, the body height, weight and BMI of intervention group had a significant difference at the level of $p<.001$ compared to those of control group (Table 1). 
Table 1. Comparison of physical properties between Intervention and Control groups

\begin{tabular}{|c|c|c|c|c|c|c|c|c|c|c|}
\hline \multirow[b]{2}{*}{ Variables } & \multirow[b]{2}{*}{ Group } & \multirow[b]{2}{*}{$\mathbf{N}$} & \multicolumn{4}{|c|}{ Intervention Groups } & \multicolumn{4}{|c|}{ Control Group } \\
\hline & & & M & SD & $Z$ value & $\begin{array}{l}\text { Asym. } \\
\text { Sig }\end{array}$ & $\mathbf{M}$ & SD & $Z$ value & Asym.Sig \\
\hline \multirow{3}{*}{ Age (Years) } & Pre test & 85 & 9,94 & 0,80 & \multirow{3}{*}{,- 207} & \multirow{3}{*}{,836 } & 9,96 & 0,77 & \multirow{3}{*}{,- 212} & \multirow{3}{*}{, 842} \\
\hline & Post test & 85 & 9,94 & 0,80 & & & 9,96 & 0,77 & & \\
\hline & Total & 170 & 9,94 & 0,80 & & & 9,96 & 0,77 & & \\
\hline \multirow{3}{*}{$\begin{array}{l}\text { Body Height } \\
\text { (cm) }\end{array}$} & Pre test & 85 & 142,97 & 6,27 & \multirow{3}{*}{$-4,344$} & \multirow{3}{*}{, $000 * *$} & 141,00 & 5,63 & \multirow{3}{*}{$-1,017$} & \multirow{3}{*}{, 293} \\
\hline & Post test & 85 & 143,89 & 6,80 & & & 141,49 & 6,23 & & \\
\hline & Total & 170 & 143,93 & 6,13 & & & 141,24 & 5,93 & & \\
\hline \multirow{3}{*}{ Body Weight (kg) } & Pre test & 85 & 38,52 & 4,72 & \multirow{3}{*}{$-3,429$} & \multirow{3}{*}{, $001 * *$} & 39,25 & 6,06 & \multirow{3}{*}{$-0,717$} & \multirow{3}{*}{,476 } \\
\hline & Post test & 85 & 36,16 & 4,93 & & & 39,12 & 5,90 & & \\
\hline & Total & 170 & 37,34 & 4,82 & & & 39,18 & 5,98 & & \\
\hline \multirow{3}{*}{$\begin{array}{l}\text { Body Mass İndex } \\
\text { (BMI) }\end{array}$} & Pre test & 85 & 18,90 & 2,47 & \multirow{3}{*}{$-5,993$} & \multirow{3}{*}{, $000 * *$} & 19,96 & 2,38 & \multirow{3}{*}{$-0,558$} & \multirow{3}{*}{, 542} \\
\hline & Post test & 85 & 17,30 & 2,63 & & & 19,79 & 2,46 & & \\
\hline & Total & 170 & 18,10 & 2,55 & & & 19,87 & 2,42 & & \\
\hline
\end{tabular}

** Significant difference at $\mathrm{p}<0.01$ level, Mann Whitney U Test=MW U Test

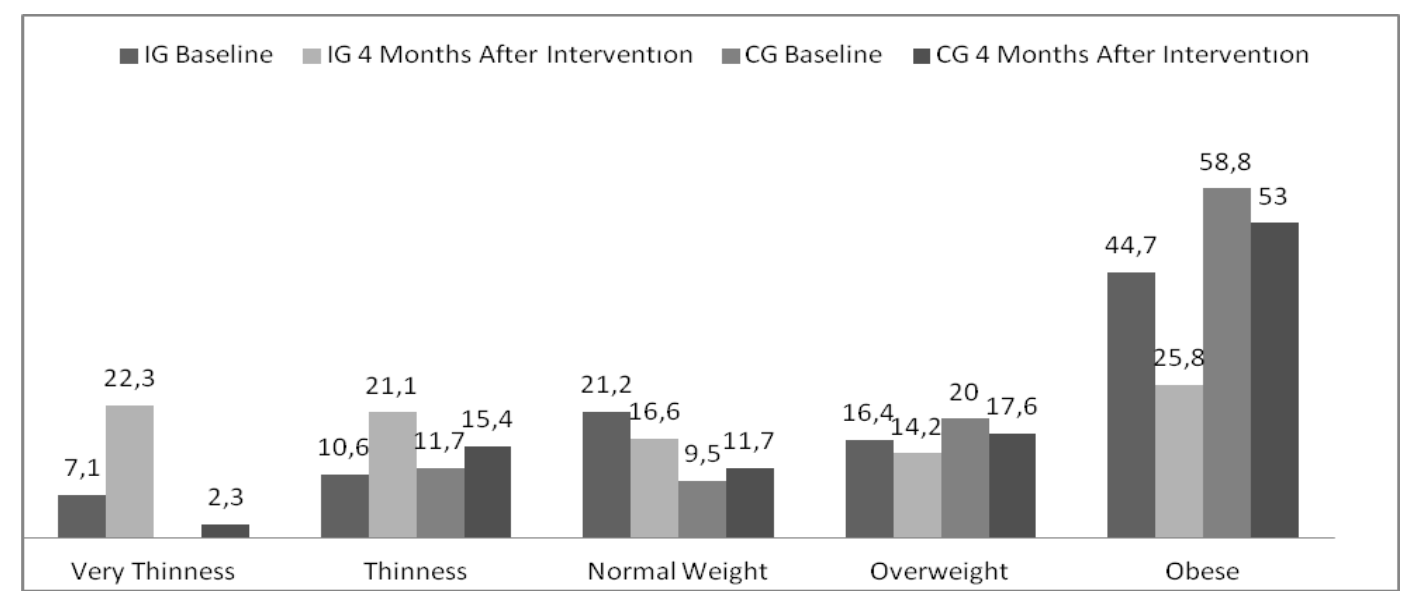

Intervention Group (IG), Control Group (CG)

Figure 1. The intervention groups (SBEP and CGPA) and control Group (CGPA) in the baseline and 4 months after the intervention Body Mass Index Z Scores

There was no significant difference between students in the body mass index at the baseline (Fig 1). However, it was determined that there was a decrease in the intervention group BMI after 4 months of intervention, whereas in the control group it was found that was no significant difference at the beginning and 4 months after the intervention. Before to SBEP, $44.7 \%$ of the intervention group was obese, $16.4 \%$ was overweight, while the proportion of those who were obese after 4 months of intervention decreased by $25.5 \%$, $14.2 \%$ to of overweight. Before to CGPA, $58,8 \%$ of the control group was obese, $20 \%$ was overweight, after 4 months intervention control group was found to have a statistically insignificant decrease in BMİ (Fig 1).

The scores and total quality of life scores that both groups obtained from the sub-dimensions of Kid-KINDL quality of scale and also their ESL are given in (Table 2). After 4 months of Intervention there were no significant differences between the groups in the friendship subscale of the HRQL-KINDL scale ( $p>0.05$ ) (Table 2).

However, intervention group's scores of total quality of life, physical well-being, emotional well-being, school, self-esteem and family sub-dimensions were found significantly high $(p<0.001)$ compared to those of control group. Similarly, after 4 months of Intervention it was found out that intervention group's ESL were higher $(p<0.001)$ than those of control group (Table 2). According to the control group of the SBEP program, the intervention group was found to have a positive effect on the students. 
Table 2. The Comparison of İntervention Groups (SBEP and CGPA) and Control Group (CGPA) After 4 Months Of İntervention On Health-Related Quality Of Life And Exercise Self-Efficacy Levels

\begin{tabular}{|c|c|c|c|c|c|}
\hline Sub- Dimensions & Group & $\mathbf{N}$ & $\mathbf{X} \pm \mathbf{S S}$ & Z Value & $\begin{array}{c}\text { Asymp. } \\
\text { Sig }\end{array}$ \\
\hline \multirow{3}{*}{ Physical Well-Being } & İntervention Groups & 85 & $16.43 \pm 2.52$ & \multirow{3}{*}{-1.764} & \multirow{3}{*}{$.004 * *$} \\
\hline & Control Group & 85 & $9.37 \pm 3.01$ & & \\
\hline & Total & 170 & $12.9 \pm 2.76$ & & \\
\hline \multirow{3}{*}{ Emotional Well-Being } & İntervention Groups & 85 & $15.12 \pm 2.83$ & \multirow{3}{*}{-1.570} & \multirow{3}{*}{$.005 * *$} \\
\hline & Control Group & 85 & $11.93 \pm 2.56$ & & \\
\hline & Total & 170 & $13.52 \pm 2.69$ & & \\
\hline \multirow{3}{*}{ self-esteem } & İntervention Groups & 85 & $15.31 \pm 2.79$ & \multirow{3}{*}{-1.295} & \multirow{3}{*}{$.007 * *$} \\
\hline & Control Group & 85 & $11.12 \pm 2.25$ & & \\
\hline & Total & 170 & $13.21 \pm 2.52$ & & \\
\hline \multirow{3}{*}{ Family } & İntervention Groups & 85 & $15.48 \pm 2.26$ & \multirow{3}{*}{-1.380} & \multirow{3}{*}{$.006^{* *}$} \\
\hline & Control Group & 85 & $11.67 \pm 2.45$ & & \\
\hline & Total & 170 & $13.57 \pm 2.35$ & & \\
\hline \multirow{3}{*}{ Friends } & İntervention Groups & 85 & $12.36 \pm 3.21$ & \multirow{3}{*}{-.630} & \multirow{3}{*}{.312} \\
\hline & Control Group & 85 & $11.96 \pm 2.48$ & & \\
\hline & Total & 170 & $12.16 \pm 2.84$ & & \\
\hline \multirow{3}{*}{ School } & İntervention Groups & 85 & $15.01 \pm 2.86$ & \multirow{3}{*}{-1.490} & \multirow{3}{*}{$.006^{* *}$} \\
\hline & Control Group & 85 & $12.06 \pm 2.63$ & & \\
\hline & Total & 170 & $13.53 \pm 2.74$ & & \\
\hline \multirow{3}{*}{ Total HRQL } & İntervention Groups & 85 & $14.95 \pm 2.76$ & \multirow{3}{*}{-1.475} & \multirow{3}{*}{$.006 * *$} \\
\hline & Control Group & 85 & $11.35 \pm 2.56$ & & \\
\hline & Total & 170 & $13.15 \pm 2.65$ & & \\
\hline \multirow{3}{*}{ ESL (point) } & İntervention Groups & 85 & $65.7 \pm 13.1$ & \multirow{3}{*}{$-2,613$} & \multirow{3}{*}{, $001 * *$} \\
\hline & Control Group & 85 & $53.4 \pm 11.2$ & & \\
\hline & Total & 170 & $59.3 \pm 12.5$ & & \\
\hline
\end{tabular}

** Significant difference at ( $>0.05), \mathrm{p}<0.01$ level, Mann Whitney U Test=MW U Test, Total Health-Related Quality of Life (Total HRQL)

After 4 months of intervention, a positive relationship at the level of $\mathrm{r}=.361 ; \mathrm{r}=.305 ; \mathrm{r}=.219$ was found between intervention group's ESL and the sub-dimensions of physical well-being, emotional well-being and self-esteem of HRLQ (Kid-KINDL) and this relationship was considered statistically significant $(p<0.01 ; p<0.05)$ (Table 3 ). In terms of the sub-dimensions of family, friends and school, a significant relationship wasn't detected between the HRQL scores of the students. After 4 months of intervention While there was a significant relationship at the level of $r=.230(p<0.05)$ between control group's ESL and the sub-dimension of friends of HRQL scores (Table 3), a significant relationship wasn't observed between their ESL and the sub-dimensions of physical well-being, emotional well-being, self-esteem, family and school $(\mathrm{p}>0.05)$ (Table $3)$. 
Table 3. The Relationship of intervention groups (SBEP and CGPA) and control group (CGPA) after 4 months of intervention on Health-Related Quality of Life and Exercise Self-Efficacy Levels

\begin{tabular}{|c|c|c|c|c|}
\hline \multirow{2}{*}{ HRQLS } & \multicolumn{2}{|c|}{ Intervention Group } & \multicolumn{2}{c|}{ Control Group } \\
\hline & \multicolumn{2}{|c|}{ ESL (Puan) } & \multicolumn{2}{c|}{ ESL (Puan) } \\
\cline { 2 - 5 } & $\mathrm{r}$ & $\mathrm{p}$ & .171 & .116 \\
\hline Physical well-being & .361 & $.003^{* *}$ & .174 & .109 \\
\hline Emotional well-being & .305 & $.005^{* *}$ & .181 & .095 \\
\hline Self-esteem & .219 & $.043^{*}$ & .065 & .553 \\
\hline Family & -.089 & .416 & .230 & $.033^{*}$ \\
\hline Friends & -.039 & .720 & .112 & .304 \\
\hline School & -.027 & .805 & $\mathrm{r}$ & \multicolumn{2}{c|}{} \\
\hline
\end{tabular}

Correlation is significant at the $0.05 ; 0.01$ level, Health Related Quality of Life Scale (HRQLS), Exercise self-efficacy levels (ESEL)

\section{Discussion}

HRQL is a multi-dimensional concept addressing to subjectivity. HRQL focuses on perception of physical, emotional, mental and social functions and the impact of health state on the quality of life [32, 33, 34]. American Academy of Paediatrics [35] suggests that exercise is an important instrument for health for all children irrespective of their mental capacity. Physical activity is considered necessary for individual physical development, coordination, growth, motivation, socialisation and having a healthy body.

This study aimed to investigate the effects of school-based exercise practices on obesity, SBEP and health-related quality of life in 9-11 year old girls. Among the intervention group and control group students, it is another purpose to determine whether there is a relationship between HRQL and ESL. According to findings; after 4 months of intervention, intervention group students differ significantly in height, weight and BMI than control group. There was no significant difference between students in the body mass index at the baseline. Before to participated in the study SBEP $44.7 \%$ of the intervention group was obese, $16.4 \%$ was overweight, while the proportion of those who were obese after 4 months of intervention decreased by $25.5 \%, 14.2 \%$ to of overweight. In the control group, the proportion of those who were obese before intervention was $58.8 \%$ and the proportion of those who were overweight was $20 \%$. after 4 months Intervention control group was found to have a statistically insignificant decrease in BMİ. Especially in developed and developing countries obesity is increasingly seen in children. Familial predisposition, dietary habits and low physical activity several factors such as are considered to be important in the development of obesity [36]. A study conducted in the United States between 1988 and 1994 found that the proportion of children over the 95th percentile of the BMI among children aged 6 to 11 years was 13.7 percent (14.7 percent for males and 12.5 percent for females). The prevalence of obesity increased by $54 \%$ over the previous decade [37]. In another study, the prevalence of obesity was found to be $8,4 \%$ and the prevalence of overweight was found to be $26,7 \%$ in 299 children aged $6-15$ years in a private elementary school with high socio economic level in Istanbul Bakırköy in 2003 [38]. These findings are parallel to our results.

On the other hand, Intervention group's body height, weight and body-mass index is significantly different compared to those of control group. A significant difference wasn't observed between both groups in terms of the sub-dimension of school of HRQL (Kid-KINDL) while intervention group's total quality of life, physical well-being, emotional well-being, self-esteem and family sub-dimensions and ESL were found significant compared to control group. Nonetheless, after 4 months of intervention, a positive relationship was found between intervention group's ESL and the sub-dimensions of physical well-being, emotional well-being and self-esteem of HRQL Scale (Kid-KINDL) whereas ESL didn't affect other sub-dimensions of HRQL. After 4 months of intervention. There was a significant relationship between control group's ESL and the sub-dimension of friends of HRQL scale, a significant relationship wasn't observed between their ESL and the sub-dimensions of physical well-being, emotional well-being, self-esteem, family and school. In the study carried out by Çakar [39] the relationship between school and quality of life was investigated among 373 children attending the primary school and adolescents. HRQL scale as used for children and adolescents as data collection tool in that study. That study revealed that a positive relationship was available between school, physical fitness, emotional well-being, family life, friend relations and school life that are the sub-dimensions of quality of life. Those results are parallel to some sub-dimensions included in our findings. A school environment is one of the environments where children spend a major part of day or improve their sportive skills after school. The low level of primary-school children's physical activity and exercise levels and increase of overweight and obese individuals creates a key environment to improve the children's exercise levels and quality of life, giving particular importance to taking protective measures at schools $[40,41]$. Our study found out a positive relationship between HRQL perceptions and ES levels of the children having attended the extracurricular 
sports activities. Therefore, the more significance is attached to physical activity and exercise at schools, the more it is required to enable children to acquire the necessary skills to keep them physically active [42]. Despite drawing attention to this requirement, the researchers have detected a range of barriers in front of efficient physical education course. Due to a great number of responsibilities given to physical education teachers, it has been suggested that the ways other than school environment need to be discovered to improve the children's exercise levels and HRQL. Therefore, it has been put forward that various extracurricular possibilities need to be developed to improve the children's many learning requirements, quality of life and exercise levels [43, 44, 45].

Top \& Ak1l [46] have investigated the effect of swimming exercise done by 32 students for 10 weeks on the children's HRQL and suggested that 10 -week swimming exercise was insufficient to affect the quality of life. According to a research carried out in the U.S.A, $4 \%$ of the primary schools, $8 \%$ of the secondary school and $2 \%$ of the high schools have participated in the physical education course and physical activities daily. Moreover, it has been revealed that $16 \%$ of the primary schools, $10 \%$ of the secondary schools and $4 \%$ of the high schools have taken part in sports activities outside the physical education course throughout a school term [42, 47]. It is required to enable children to have opportunities to participate in extracurricular sports activities (e.g. school teams, recreation and other activities) through schools, communities and/or after-school programs in addition to the opportunities in the school age. In another study in which HRQL has been assessed according to the sub-dimensions of Kid-KINDL quality of life scale, it has been found out that the hearing-impaired children have got the highest score in the sub-dimension of physical well-being and this finding doesn't show a significant difference statistically compared to healthy children. On the other side, the hearing-impaired children have obtained the lowest score in self-esteem among the sub-dimensions of quality of life scale and this finding shows a significant difference statistically compared to healthy children $[48,49,50]$ have suggested in their studies that the activity performed in physical education course needs to let you have fun, joy and satisfaction. It has been shown that the high-school students' high levels of physical activity and exercise have a positive impact on HRQL. Also, it is put forward that boys benefit from such sports activities more than girls do and hence girls need to be encouraged more to take part in sports activities. The children, whose aim is to do sportive exercises frequently, spend more time on exercises compared to those who don't aim to do exercises, It can be suggested that this process has contributed significantly to HRQL levels.

Consequently; in the study found that the decrease in the control group was not statistically significant while the proportion of the students who were the intervention group's after 4 months intervention obese and overweight decreased significantly. After 4 months of intervention, it was determined that the total quality of life, physical well-being, emotional well-being, self-esteem and family sub-dimension of the intervention group were significant according to the control group. However, it was found that the intervention group had a positive correlation between physical activity, emotional well-being, and self-esteem subscale of the ESL and HRQL (Kid-KINDL) scale. But, It was observed that there was no significant relationship between the subgroups of the control group and the HRQL scale. It is aimed to increase the extracurricular sports activities besides the SBEP due to the direct relation with HRQL. Increasing participation in SBEP and extracurricular sports activities on schools can be a vehicle for hope in terms of HRQL. On the other hand, supporting children with SBEP by decreasing their sedentary time has a direct sustainable potential in terms of ESL. Primary school students should increase their extracurricular sports activities, make these activities a part of the school and be associated with HRQL. Gaining school-based SBEP habits from childhood, making extracurricular activities to move away from sedentary life a part of life will benefit from obesity prevention.

\section{Conflicts of Interest}

There isn't any conflict of interest to be declared regarding the manuscript.

\section{REFERENCES}

[1] Rezapour B, Mostafavi F, Khalkhali H. The Effect of School-Based Intervention on Obese and Overweight Students in Urmia. Global J H Sci 2017; 9 (3); 283-288.

[2] Asghar R, Kourosh S, Khairollah A, Diana S, Farhad I, Sarokhani M. Investigation of the Prevalence of Obesity in Iran: a Systematic Review and Meta-Analysis Study. Acta Med Iranica 2015; 53(10).

[3] Van Cleave J, Gortmaker S L, Perrin J M. Dynamics of obesity and chronic health conditions among children and youth. J Am Med Assoc 2010; 303:623-630.

[4] Lustyk MK, Widman L, Paschane AA, Olson KC. Physical activity and quality of life: Assessing the influence of activity frequency, intensity, volume, and motives. Behavioral Med 2004; 30:124-131.

[5] Diener E, Suh E M, Lucas R E, Smith H L. Subjective well-being: Three decades of progress. Psych Bulletin 1999; 123(2):276-303.

[6] Petersson C, Rune J, Simeonsson R J, Enskar K, Huus K. Comparing children's self-report instruments for health-related quality of life using the International Classification of Functioning, Disability and Health for Children and Youth (ICF-CY). Health and Qual of Life Out 2013; 11:75; 1-10. 
[7] Orley J, Kuyken W. Quality of life assessment: International perspectives. proceedings of the joint meeting organized by the who and the foundation IPSEN in Paris 1993; 41-57.

[8] Eser F, Yüksel H, Baydur H, Erhart M, Saatlı G, Özyurt B C, Özcan C, Sieberer U R. The Psychometric properties of the new Turkish generic health-related quality of life questionnaire for children (Kid-KINDL).Turkısh Journal of Psychiatry 2008; 19(4): 409-417.

[9] Griew P, Page A, Thomas S, Hillsdon M, Cooper AR. The school effect on children's school time physical activity: the PEACH project. Prev Med 2010; 51:282-286.

[10] Sharma M. International school-based interventions for preventing obesity in children. Obes Rev 2006; 8:155-167.

[11] Mota J, Silva P, Santos MP, Ribeiro JC, Oliveira J, Duarte JA. Physical activity and school recess time: differences between the sexes and the relationship between children's playground physical activity and habitual physical activity. J Sports Sci 2005; 23:269-275.

[12] Groffik D, Sigmund E, Frömel K, Chmelík F, Nováková Lokvencová $\mathrm{P}$. The contribution of school breaks to the all-day physical activity of 9- and 10-year-old overweight and non-overweight children. Int J Pub Health 2012; 57:711-718.

[13] Gonzalez-Suarez C, Worley A, Grimmer-Somers K, Dones V. School-based interventions on childhood obesity: A meta-analysis. Am J Prev Med 2009; 37:418-427

[14] Brown T, Summerbell C. Systematic review of school-based interventions that focus on changing dietary intake and physical activity levels to prevent childhood obesity: An update to the obesity guidance produced by the National Institute for Health and Clinical Excellence. Obes Rev 2009; 10: $110-141$

[15] Savaşhan Ç, Sarı O, Aydoğa Ü, Erdal M. İlkokul çağındaki çocuklarda obezite görülme sıklığ 1 ve risk faktörleri. Türk Aile Hek Derg 2015; 19 (1): 14-2.

[16] Bandura A. Self-efficacy: The Exercise of control. New York 1997: W.H. Freeman and Company.

[17] Bandura A. Social cognitive theory: An agentic perspective. Annual Review of Psychology 2001; 52, 1-26.

[18] Bandura A. Exercise of personal and collective efficacy in changing societies. In: A. Bandura (Ed.), Self-efficacy in changing societies (pp. 1-45). New York 1995: Cambridge University Press.

[19] Alzubaidi A S, Kazem A M. Perception of physical self-efficacy and body 1mage among omani basic school children. Int. J. Learn. Man. Sys 2013; 1(1), 11-17.

[20] Strauss R S, Rodzilsky D, Burack G. Colin M. Psychological correlates of physical activity in healthy children. Arch of Pedia and Adol Med 2001; 155, 807-902.

[21] Alzubaidi A S, Mansy M A. Relationship between health beliefs and body image as perceived by secondary school students in Oman. Paper to be presented at the national conference on applied cognitive psychology 2007; 29-30th November.

[22] Mansy M A, Alzubaidi A, Al-Jamali F A. Health beliefs and its relationship with quality of life for Sultan Qaboos University Students. Psychology and Quality of Life 2006; SQU, Muscat, Oman. 17-19 December.
[23] Dalton W T, Schetzina K E, Pfortmiller D T, Slawson D L, Frye W S. Health behaviors and healthrelated quality of life among middle school children in Southern Appalachia: Data from the winning with wellness project. J Pedia Psyc 2011; $36(6), 677-686$

[24] Swallen K C, Reither E, Haas S, Meier A M. Overweight, obesity, and health-related quality of life among adolescents: The national Longitudinal Study of Adolescent Health. Pediatrics 2005; 115(2), 340-347.

[25] Tsiros M D, Olds T, Buckley J D, Grimshaw P, Brennan L, Walkley J, Hills AP, Howe PR, Coates AM. Health-related quality of life in obese children and adolescents. Int Jo Obes 2009; 33(4), 387-400.

[26] Bisegger C, Cloetta B, Von Rueden U, Abel T. Ravens S. Health-related quality of life: Gender differences in childhood and adolescence. Prev Med 2005; 50(5), 281-291.

[27] Herman K M, Hopman W M, Vandenkerkhof E G, Rosenberg M W. Physical activity, body mass index, and health-related quality of life in Canadian adults. Med and Sci Spor and Exer 2012; 44(4), 625-636.

[28] Brovold T, Skelton D A, Sylliaas H, Mowe M, Bergland A. Association between health-related quality of life, physical fitness, and physical activity in older adults recently discharged from hospital. J A and Phy Act 2014; 22(3), 405-413.

[29] Elavsky S, McAuley E, Motl R W, Konopack J F, Marquez D $\mathrm{X}, \mathrm{Hu} \mathrm{L}$, Jerome GJ, Diener E. Physical activity enhances long-term quality of life in older adults: Efficacy, esteem, and affective influences. An Behav Med 2009; 30(2):138-145.

[30] WHO: Growth reference data for 5-19 years: WHO Reference; 2007. http://www.who.int/growthref/en.

[31] Bozkurt N. Investigation of the breast cancer patients exercise self- efficacy scale Turkish reliability and validity. Izmir: Ege University Institute of Health Sci 2009.

[32] Ravens-Sieberer U, Erhart M, Wille N, Wetzel R, Nickel J, Bullinger M. Generic health-related quality-of-life assessment in children and adolescents: methodological considerations. Pharm Econo 2006; 24:1199-1220.

[33] Bowling A. Measuring health: a review of quality of life measurement scales. Buckingham: Open University Pr 2005.

[34] Bullinger M, Schmidt S, Petersen C. Assessing quality of life of children with chronic health conditions and disabilities: a European approach. Int J Rehabil Res 2002; 25:197-206.

[35] American Academy of Pediatrics. Exercise for children who are mentally retarded. Pediatrics 1987; 80: 447-448.

[36] Weker H, Baranska M. Models of safe nutrition of children and adolescents as a basis for prevention of obesity. Med Wieku Rozwoj 2011; 15(3):288-97.

[37] McDowell MA, Fryar CD, Ogden CL. Anthropometric reference data for children and adults: United States, 1988-1994. Vital Health Stat 2009; 249:1-68

[38] Öztora S, Hatipoğlu S, Barutçugil MB, Salihoğlu B, Yıldırım R, Şevketoğlu E. İlköğretim çağındaki çocuklarda obezite prevalansının belirlenmesi ve risk faktörlerinin araştırılması. Bakırköy Tıp Derg 2006; 2:11-4. 
[39] Cakar F S. School attachment and quality of life in children and adolescents of elementary school In Turkey, Educ Res 2011; 1(9): 1465-1471.

[40] Eisenmann J C. Insight into the causes of the recent secular trend in pediatric obesity: common sense does not always prevail for complex, multi-factorial phenotypes. Prev Med 2006; 42(5):329-335.

[41] Hardman K. Physical education in schools: a global perspective. Kinesiology 2008; 40(1):5-28.

[42] Lee S M, Burgeson C R, Fulton J E, Spain C G. Physical education and physical activity: results from the school health policies and programs study 2006. J Sch Health 2007; 77(8):435-463.

[43] Jenkinson K, Benson A C. Barriers to providing physical education and physical activity in Victorian State secondary schools. Aust J Teach Educ 2010; 35(8):1-17.

[44] Hyndman B, Telford A, Finch C, Benson A. Moving physical activity beyond the school classroom: a social-ecological insight for teachers of the facilitators and barriers to students' non-curricular physical activity. Aust J Teach Educ 2012; 37(2):1-24.
[45] Pangrazi R P, Beighle A. Dynamic Physical Education for Elementary School Children. San Francisco: Benjamin Cummings 2010.

[46] Top E, Akıl M. 10 haftalık yüzme egzersizinin hafif düzeyde zihinsel engelli bireyler ve ailelerinin yaşam kalitesine etkisi. J S and perfor res 2017; 8(1): 1-9.

[47] Coatsworth J D, Conroy D E. Youth sport as a component of organized afterschool programs. New Directions for Youth Development 2007; (115):57-74.

[48] Ekim A, Ocakçı A F. 8-12 yaș arası ișitme engelli çocuklarda yaşam kalitesi. Ankara Sağlık Hizmetleri Dergisi 2012; Cilt 11, Say1 1.

[49] Granero-Gallegos A, Baena-Extremera A, Pérez-Quero F J, Ortiz-Camacho M M, Bracho-Amador C. Analysis of motivational profiles of satisfaction and importance of physical education in high school adolescents. J Sports Sci Med 2012; 11(4):6, 14-23.

[50] Camacho-Miñano M J, LaVoi N M, Barr-Anderson D J. Interventions to promote physical activity among young and adolescent girls: a systematic review. Health Educ Res 2011; 26(6):1025-49. 